\section{Comparing Seeded Organic- fiber Mat with Direct Soil Seeding for Warm-season Turfgrass Establishment}

\author{
K.L. Hensler, ${ }^{1}$ \\ B.S. Baldwin, ${ }^{2}$ and \\ J.M. Goatley, Jr. ${ }^{3}$
}

ADPTOA-ADE- mulch, weed control

Summary. A bioorganic fiber seeding mat was compared to traditional seeding into a prepared soil to ascertain any advantages or disadvantages in turfgrass establishment between the planting methods. Bahiagrass (Paspalum notatum), bermudagrass (Cynodon dactylon), carpetgrass (Axonopus affinis), centipedegrass (Eremochloa ophiuroides), st. augustinegrass (Stenotaphrum secundatum), and zoysiagrass (Zoysia japonica) were seeded at recommended levels in May 1995 and July 1996. The seeding methods were evaluated under both irrigated and nonirrigated conditions. Plots were periodically rated for percent turf coverage; weed counts were taken about 4 weeks after study initiation. Percent coverage ratings for all grasses tended to be higher for direct-seeded plots under irrigated conditions in both years.

Bermudagrass and bahiagrass established rapidly for both planting methods under either irrigated or nonirrigated conditions. Only

Department of Plant and Soil Sciences, Mississippi State University, Mississippi State, MS 39762. Mississippi Agricultural Forestry Experiment Station Journal no. J-9670. The cost of publishing this paper was defrayed in part by the payment of page charges. Under postal regulations, this paper therefore must be hereby marked advertisement solely to indicate this fact.

${ }^{1}$ Former graduate research assistant; presently Extension Horticulture Agent, University of Tennessee, Lawrenceburg, TN 38464

${ }^{2}$ Associate professor and agronomist.

${ }^{3}$ Professor and agronomist. carpetgrass and zoysiagrass tended to have greater coverage ratings in nonirrigated, mat-seeded plots in both years, although the percent plot coverage ratings never reached the minimum desired level of $80 \%$. In both years, weed counts in mat-seeded plots were lower than in direct-seeded plots. A bioorganic fiber seeding mat is a viable method of establishing warm-season turfgrasses, with its biggest advantage being a reduction in weed population as compared to direct seeding into a prepared soil.

A $n$ even distribution of grass seedlings can be difficult to accomplish when establishing turf. Lightly incorporating turfgrass seed into the surface of a tilled soil continues to be the standard establishment method because soil moderates temperatures, stabilizes and enhances moisture conditions for germination, and decreases seed injury due to drying (Musser and Perkins, 1969). Poor establishment from seed may be due to poor seed-to-soil contact, seed and/or soil movement due to excessive rainfall or irrigation, or unfavorable changes in soil moisture or temperature that may inhibit or delay germination. Additionally, weed seed germination is promoted by soil tillage and weeds reduce turfgrass stands by their competitive nature.

The principle environmental factors that affect turf establishment are temperature, moisture, light, and wind (Watschke and Schmidt, 1992). These factors impact stand establishment by influencing the environment surrounding germinating seed. Mulching enhances seed germination and turfgrass establishment at seed dispersal and is effective because it buffers the previously mentioned environmental extremes. Mulches conserve soil moisture by moderating soil temperatures and reducing wind-induced evaporation (Barkley et al., 1965; Harris and Yao, 1923; McGinnies, 1960), and reduces surface soil erosion and compaction that results from the impact of raindrops or irrigation, thereby reducing runoff and increasing moisture infiltration (Adams, 1966).

To use the benefits of mulch, seed carriers made of biodegradable organic and inorganic materials have been introduced. These come in different forms: a mat made predominantly of plant fiber material or a loose mulch made of wood fiber or recycled newspaper (Hensler and Baldwin, 1995). The mat carriers are designed to keep the seed in place, maintain moisture to promote germination and seedling establishment, permit root development through the mat into the soil, and reduce weed seed germination and development. The target markets for these products range from spot renovations in home lawns to establishment of large areas such as highway rights of ways. Additionally, the mat comprised predominantly of plant has proven successful as a substrate in soilless sod production (Hensler et al., 1998).

An organic fiber mat composed of $50 \%$ kenaf fiber (Hibiscus cannabinus) and 50\% aspen (Populus sp.) wood fiber by-products combines the improved tensile strength of kenaf with the water holding capacity of the wood fiber. Our objective was to compare turfgrass establishment with a seeded kenaf and wood fiber mat to traditional, direct seeding into a prepared planting bed under both irrigated and nonirrigated conditions.

\section{Materials and methods}

Seeded organic fiber mat composed of $50 \%$ kenaf fiber and $50 \%$ aspen wood fiber $(\mathrm{w} / \mathrm{w})$ was obtained from the manufacturer (Mississippi Mat Line, Charleston, Miss.). Seed of bahiagrass 'Pensacola,' bermudagrass 'Arizona common,' carpetgrass 'Common,' centipedegrass 'Common,' st. augustinegrass (no cultivar provided, although seed tag information indicated it was seed that was harvested from 'Raleigh') and zoysiagrass ' $\mathrm{Ko}$ rean common' were obtained from local seed distributors. The mats were custom made by Mississippi Mat Line (Charleston, Miss.) and prepared by mixing kenaf and wood fibers (50:50 $\mathrm{w} / \mathrm{w}$ ) with trace amounts of ultraviolet-degradable low melt polyester binding agent. The fiber was then passed through an oven to melt the binding agent and sterilize the mat, and upon cooling, a proprietary water retention agent was applied at a rate of $0.35 \mathrm{oz} /$ $\operatorname{yard}^{2}\left(11.9 \mathrm{~g} \cdot \mathrm{m}^{-2}\right)$. Finally, the appropriate rate of seed for the respective species was applied to the mat. Mats were composed of $9.6 \mathrm{oz} / \mathrm{yard}^{2}$ mixed fiber $\left(326 \mathrm{~g} \cdot \mathrm{m}^{-2}\right)$ and were 0.3 inch $(0.75 \mathrm{~cm})$ thick. The only difference between mats were seed type and seeding rates which were formulated ac- 


\begin{tabular}{|c|c|c|c|}
\hline \multirow[b]{2}{*}{ Species } & \multirow[b]{2}{*}{ Recommended range $^{\mathrm{z}}$} & \multicolumn{2}{|c|}{ Actual rate } \\
\hline & & 1995 & 1996 \\
\hline & $\mathrm{lb} / 1000 \mathrm{ft}^{2}\left(\mathrm{~kg} \cdot \mathrm{ha}^{-1}\right)$ & & \\
\hline Bermudagrass & $1.0-2.0(49-98)$ & $1.8(88)$ & $1.8(88)$ \\
\hline Carpetgrass & $1.5-5.0(74-245)$ & $3.0(146)$ & $2.6(127)$ \\
\hline Centipedegrass & $0.2-2.0(10-98)$ & $2.5(123)$ & $2.7(132)$ \\
\hline
\end{tabular}

${ }^{\mathrm{z}}$ Recommended range and actual seeding rates in pounds of pure live seed (PLS) per $1000 \mathrm{ft}^{2}$ (kilograms/ha) as recommended by Emmons, 1995 .

cording to the recommendations of Emmons (1995) (Table 1).

All trials were conducted at the Plant Science Research Center at Mississippi State University, Starkville, on a site with less than $0.25 \%$ slope. The soil type was a Marietta fine silt loam (Fine-loamy, siliceous, thermic Fluvaquentic Eutrochrepts) with a $\mathrm{pH}$ of 5.7. Plots were arranged in a splitplot design with four replications. Whole plots of the respective turf species measured 10 (ximes: $x) 5 \mathrm{ft}(3.0$ (ximex $x)$ $1.5 \mathrm{~m}$ ). Subplots consisted of planting method and measured 5 (ximex) $5 \mathrm{ft}(1.5$ (Ximesx) $1.5 \mathrm{~m}$ ). Seeded mats were precut and unrolled to cover half the plot with the seed side being placed down according to manufacturer recommendations. Seed for the direct-seeded subplots were distributed over a tilled soil with a drop spreader and the area was raked lightly to improve seed-tosoil contact. Two separate tests were established each year with one test being irrigated and the other being nonirrigated. The irrigated test was watered as needed to maximize turf establishment and development, while the nonirrigated test received supplemental irrigation one time only at establishment for the sole purpose of ensuring the mat would adhere to the soil.

In 1995, the irrigated and nonirrigated tests were initiated on 11 and 13 May, respectively, and ran through mid-September. The 1996 studies for irrigated and nonirrigated trials were initiated on 11 and 24 July, respectively, and the trials were conducted until 2 Oct. The July planting date in 1996 was later than desirable due to unforeseen problems at the manufacturing facilities. The criterion for comparison were percent plot coverage and weed suppression during the first year of establishment. Since components of plot coverage include seed and/or soil movement after sowing, and resulting seedling distribution, these constituents were considered when evaluating plot coverage. Plots were visually estimated for percent turfgrass cover at 12 and 18 weeks after initiation (WAI) in 1995, while the 1996 studies were evaluated at 3, 6, 8, 10 , and 12 WAI. Turf cover ratings were considered aesthetically acceptable if they were ${ }_{\text {(xegequal })} 80 \%$. Weed counts identifying any plant other than the intended turfgrass species were taken about 4 weeks after study initiation for both moisture regimes from each seeding method subplot. Nine random observations were taken on each plot by counting the number of emerging and existing weeds within a $1 \mathrm{ft}^{2}(0.09$ $\mathrm{m}^{2}$ ) area and the values were averaged. All data were subjected to analysis of variance. Rainfall data were collected from the Plant Science Research Center weather station located about $2000 \mathrm{ft}$ $(610 \mathrm{~m})$ from the research sites.

The experimental design for each irrigation regime was a split plot with four replications of mat-seeded or conventional seeded plots for each turfgrass. An analysis of variance was performed on the data and mean separation done with Fisher's protected LSD procedure with a significance level of 0.05 (SAS Institute, 1987).

\section{Results and discussion}

IRRIGATED fRials: Bermudagrass subplots reached $100 \%$ coverage within 12 weeks in 1995 (Table 2). In the same time period bahiagrass covered about $85 \%$ of the plot. For these grasses, the seeding method had no effect on coverage. In contrast, centipedegrass averaged $96 \%$ coverage with direct seeding, while the mat-seeded plots averaged $71 \%$ coverage. However, by 18 WAI there was no difference in centipedegrass coverage between seeding methods. Carpetgrass, st. augustinegrass, and zoysiagrass did not achieve an acceptable $80 \%$ coverage within the 18 week period.

At $18 \mathrm{WAI}$, the percent coverage in direct-seeded plots was greater than mat-seeded plots for st. augustinegrass. A similar trend was observed with carpetgrass, centipedegrass and zoysiagrass, although the differences were not significant. Bahiagrass and bermudagrass showed no differences between direct-seeded and mat-seeded plots after 18 weeks.

Where statistical differences were observed in 1996, the direct-seeded plots had higher percent coverage than did mat-seeded plots across grass species (Table 2). Neither zoysiagrass or st. augustinegrass plots reached the minimum desirable $80 \%$ cover through 12 weeks, but unlike 1995 , centipedegrass and carpetgrass performed better than the acceptable minimum $80 \%$ coverage by the end of the trial (Table 2). By 10 WAI both bermudagrass and bahiagrass had ${ }_{[\text {Xgequal })} 80 \%$ cover in the direct seeded plots, but for mat-seeded plots only bahiagrass reached $80 \%$ cover by 12 WAI.

Under irrigated conditions, differences between seeding methods were expected to be minimal as the moisture conserving effects of the mat were minimized by applying water on an as needed basis. Where there were differences in plot coverage, the direct-seeded plots tended to have cover ratings that were equal to or higher than those of mat-seeded plots both years of the irrigated trials.

AENRRAGATED-TRAals: Rainfall is obviously critical to establishment of grasses seeded without supplemental irrigation, and rainfall events in central Mississippi in the late spring and summer are typically associated with pass- 
Table 2. Percent plot coverage comparisons of direct-seeded and mat-seeded turfgrass plots planted under irrigated conditions on either 11 May 1995 or 11 July 1996.

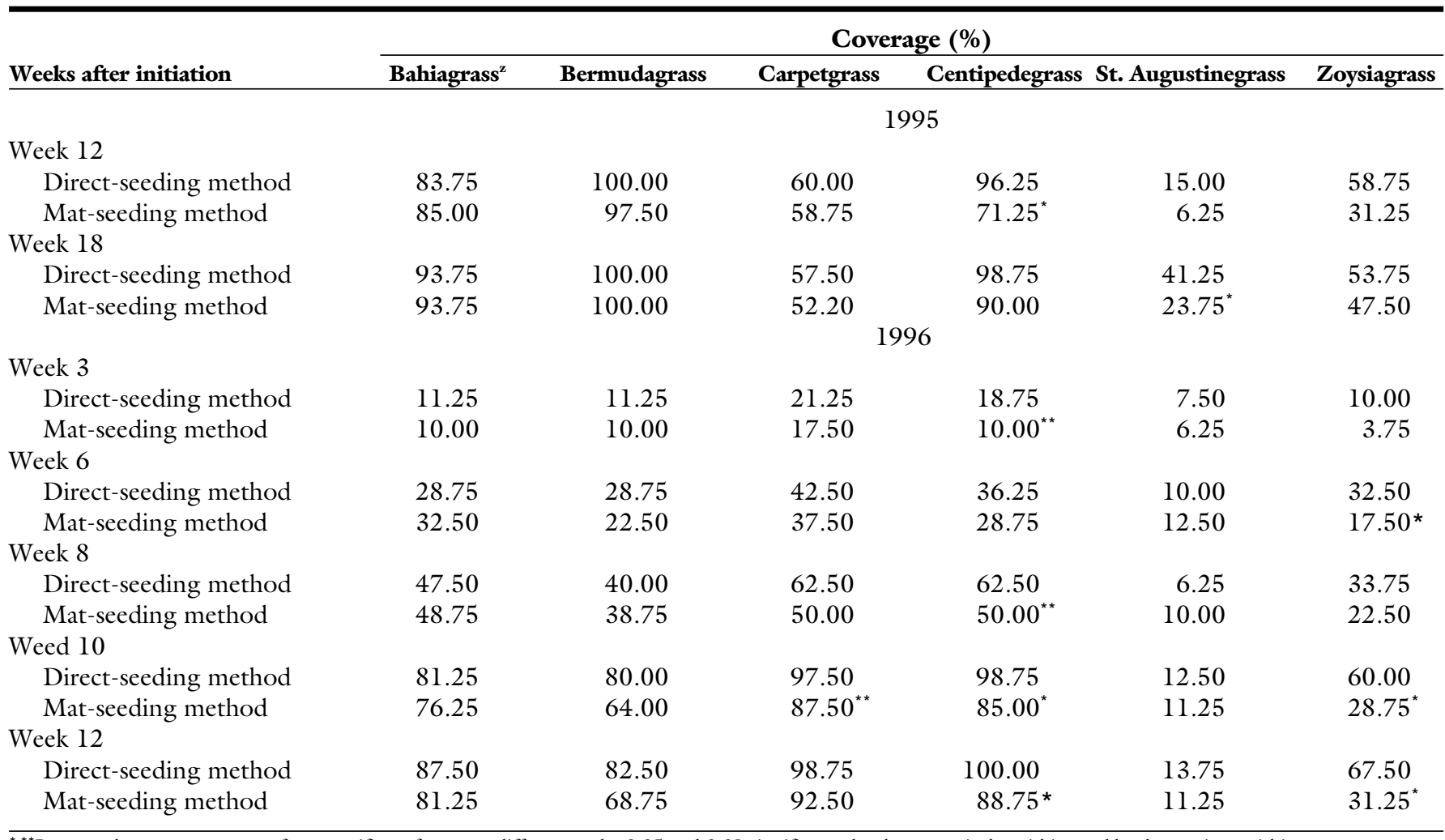

"** Percent plot coverage means for a specific turfgrass are different at the 0.05 and 0.01 significance levels, respectively, within weekly observations within a year.

ing thunderstorms which can result in large amounts of rain in very short time periods. Particularly critical to establishment is the rainfall during the first 3 weeks after seeding. In 1995 rainfall amounts in three separate rainfall events were $0.7,0.25$, and 2.4 inches $(1.8,0.6$, and $6.1 \mathrm{~cm})$ of rain, respectively (Table 3 ). Through the first 12 weeks until the first plot coverage ratings (11 May through 3 Aug.) the rainfall total was 9.4 inches $(23.9$ $\mathrm{cm}$ ) and from week 13 to 18 (4 Aug. through 14 Septe.) the rainfall total was 5.9 inches $(15 \mathrm{~cm})$. In 1996, the late planting date of 24 July was of obvious concern, but rainfall during the first 3 weeks after planting equaled $2.5,0.7$, and 1 inches $(6.3,1.8$, and $2.5 \mathrm{~cm}$ ) respectively, benefitting seedling germination and establishment (Table 3). Moisture was generally not a limiting factor in turf growth in 1996 for the nonirrigated plots except for the period from 15-28 Aug. when only 0.2 inches $(0.5 \mathrm{~cm})$ of rain occurred. Based on average precipitation data for the region (USDA, 1973), the rainfall amounts for 1995 were very near anticipated totals, while those for the experimental period of 1996 were above average.
By 12 weeks after planting in 1995 , bermudagrass and bahiagrass in nonirrigated plots exceeded $95 \%$ coverage, with no statistical difference noted between mat-seeded and directseeded plots (Table 4). Bermudagrass and bahiagrass were the only grasses to reach acceptable levels of coverage during the nonirrigated portion of this research. Though no statistical differences were evident, carpetgrass coverage tended to be higher when seeded in the organic fiber mat, while centipedegrass that was direct-seeded proved to be statistically superior. Still, the highest coverage rating for any grass species other than bermudagrass or bahiagrass was $£ 35 \%$ (Table 4 ).

At 18 WAI most plots showed little increase in coverage from the 12 week observations, and in some cases actually lost coverage. This was due to limited rainfall during this time period. For the 4 weeks prior to the 18 week observation date, only 0.6 inches $(1.5 \mathrm{~cm})$ of rain fell (Table 4$)$, resulting in drought stress. When directseeded and mat-seeded plots were compared, the trend showed that matseeded plots performed better than direct-seeded plots, with the exception of bermudagrass (already at $100 \%$ coverage) and centipedegrass (Table 4 ). Results of this study indicated that the mat may aid in retaining soil moisture, therefore having a positive, though somewhat limited, effect on seed germination and survival.

In 1996, mat-seeded carpetgrass had higher coverage ratings than direct-seeded plots at 3 and 8 WAI, while mat-seeded zoysiagrass plots had higher cover ratings at $3,6,8$, and 10 WAI (Table 4). However, the zoysiagrass ratings again were all less than $80 \%$ at any date. All other species had similar cover ratings regardless of seeding methods.

Bermudagrass and carpetgrass had cover ratings greater than $80 \%$ by 8 WAI for either planting method, while bahiagrass and centipedegrass did not achieve the $80 \%$ target cover, but were at least $65 \%$ by 8 WAI (Table 4 ). Surprisingly, bermudagrass and bahiagrass plots in the nonirrigated trial tended to have higher cover ratings than their irrigated counterparts in 1996. No statistical comparisons can be made between the moisture regimes due to the differences in planting dates, but the plots were located in a similar location at the research center and were established within 2 weeks of 
Table 3. Weekly rainfall amounts following initiation of direct and mat-seeded turfgrass trials in 1995 and 1996.

\begin{tabular}{|c|c|c|c|}
\hline \multicolumn{2}{|c|}{1995} & \multicolumn{2}{|c|}{1996} \\
\hline Week $^{\mathrm{z}}$ & $\begin{array}{c}\text { Rainfall }^{\mathrm{y}} \\
{[\text { inches }(\mathrm{cm})]}\end{array}$ & Week & $\begin{array}{c}\text { Rainfall } \\
{[\text { inches }(\mathbf{c m})]}\end{array}$ \\
\hline 11-17 May & $0.7(1.78)$ & 11-17 July & $0.8(2.08)$ \\
\hline 18-24 May & $0.1(0.25)$ & 18-24 July & $0.8(2.08)$ \\
\hline 25 May-1 June & $2.4(6.10)$ & 25-31 July & $2.5(6.35)$ \\
\hline 2-8 June & $0.0(0.00)$ & 1-7 Aug. & $0.7(1.78)$ \\
\hline 9-15 June & $0.3(0.76)$ & 8-14 Aug. & $1.0(2.54)$ \\
\hline 16-22 June & $1.2(3.05)$ & 15-21 Aug. & $0.0(0.00)$ \\
\hline 23-29 June & $1.3(3.30)$ & 22-28 Aug. & $0.2(0.51)$ \\
\hline 30 June-6 July & $1.6(4.06)$ & 29 Aug.-4 Sept. & $2.2(5.59)$ \\
\hline 7-13 July & $0.2(0.51)$ & 5-11 Sept. & $0.3(0.76)$ \\
\hline 14-20 July & $0.0(0.00)$ & 12-18 Sept. & $0.6(1.52)$ \\
\hline 21-27 July & $0.2(0.51)$ & 19-25 Sept. & $0.8(2.08)$ \\
\hline 28 July-3 Aug. & $1.5(3.81)$ & 26 Sept.-2 Oct. & $1.2(3.05)$ \\
\hline 4-10 Aug. & $4.6(11.68)$ & Total & $11.1(28.19)$ \\
\hline 11-17 Aug. & $0.8(2.08)$ & & \\
\hline 18-24 Aug & $0.0(0.00)$ & & \\
\hline 25-31 Aug. & $0.0(0.00)$ & & \\
\hline 1-7 Sept. & $0.2(0.51)$ & & \\
\hline 8-14 Sept. & $0.4(1.02)$ & & \\
\hline Total & $15.5(39.37)$ & & \\
\hline
\end{tabular}

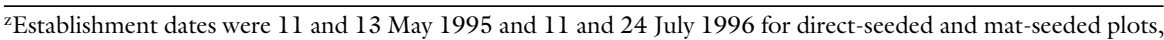
respectively.

yCumulative rainfall per week based on U.S. Department of Agriculture weather summary reports.

each other. The immediate differences in cover observed for the trials were apparently due to the initial establishment of the plots. At $3 \mathrm{WAI}$ of each trial, the ratings for the nonirrigated plots were consistently higher than those for the irrigated trial for almost all grasses. This indicated that while our intent was to eliminate moisture stress as a possible limitation in the irrigated trial, there is the likelihood that our irrigation methods were still less than satisfactory for optimizing seed germination and seedling growth and development.

\#EED-GOUNTS- In every case, regardless of year or species, irrigated, matseeded plots had fewer emerging weeds than direct-seeded plots at 4 WAI (Table 5). This trend was also observed for nonirrigated plots, although statistical differences were not evident between the seeding methods for bermudagrass and carpetgrass in 1995 , nor centipedegrass and st. augustinegrass in 1996. In each study the same trend was observed: the matseeded plots had lower numbers of weeds and fewer germinated and established grass seedlings.

The weed counts reflect the influence of temperature and light on turf establishment. The mat apparently sta- bilizes soil temperatures by acting like a mulch, thus minimizing soil temperature fluctuations that are required for germination by some weed species. The mat also acts as a light barrier that can inhibit weed seed, as well as turfgrass seed, germination in light-dependent species (Hendricks et al., 1968).

\section{Conclusions}

Under irrigated conditions, there was no advantage in establishing warmseason turfgrasses with the mat-seeding method as compared to direct seeding into a prepared soil. Where statistical differences were indicated, the direct-seeded plots had greater percent coverage ratings. When planted under nonirrigated conditions, there were limited improvements in the establishment of carpetgrass and zoysiagrass for the mat-seeded grasses, though neither species ever attained the minimum desired level of 80 percent coverage through the duration of either study in 1995 or 1996.

There are several concerns with mat-seeding that must be researched further to optimize turf establishment from a mat carrier. First of all, roots from germinating seeds in the mat must eventually reach the soil surface for successful establishment. The spatial separation between seed and soil is an obvious barrier that must be overcome and the manufacturer's recommendation of placing the mat seedside down is designed to maximize root penetration in the soil. However, the role of light in the seed germination process could also be a factor in treatment performance. Research by Hensler (1996) reported higher levels of seed germination and turf establishment for creeping bentgrass (Agrostis stolonifera var. palustris) and hard fescue (Festuca longifolia), both smaller seeded species, when the seed mat was installed seed-side up rather than the recommended seed-side down. Because a species may have a maximum seeding depth, but not a minimum depth, less (i.e., thinner) mat coverage or thickness may be required for germination with some light-dependent species. It is possible the 0.2 to 0.3 inch thick mat results in much different light penetration than soil coverage. Seed planted too deep (i.e., either in the soil or under a significant mat thickness) may exhaust carbohydrates and die before leaves emerge (Forbes and Ferguson, 1948; Madison, 1966; Murphy and Arny, 1939; Plummer, 1943). Additionally, seed that responds to light for germination such as zoysiagrass (Portz et al., 1981; Yeam et al., 1981) should not be planted deeper than 0.2 to 0.5 inch (Madison, 1966). Light and planting depth may or may not be a factor when using the 0.2 to 0.3 inch thick fiber mat due to its loosely woven nature, but this must be researched further.

While not always significantly enhancing turf coverage as compared to traditional direct soil seeding techniques, seeded-mat carriers are a viable means of establishing warm-season turfgrasses from seed. Of the species of warm-season turfgrasses used in this trial, common bermudagrass, bahiagrass, centipedegrass, and carpetgrass are often established by seed. Limited seed is available for st. augustinegrass and zoysiagrass cultivars, and their establishment from seed is typically limited due to seed availability, poor germination rates, or seed purity problems. Of the commonly seeded grasses, bermudagrass and bahiagrass establishment was highly successful for both seeding methods and irrigation regimes in either year (Tables 2 and 4). Centipedegrass and 
Table 4. Percent plot coverage comparisons of direct-seeded and mat-seeded turfgrass plots planted under nonirrigated conditions on 13 May 1995 or 24 July 1996.

Coverage (\%)

Weeks after initiation $\begin{array}{lllll}\text { Bahiagrass }^{z} & \text { Bermudagrass } & \text { Carpetgrass } & \text { Centipedegrass St. Augustinegrass } & \text { Zoysiagrass } \\ & & \end{array}$

1995

Week 12

Direct-seeding method

Mat-seeding method

Week 18

Direct-seeding method

Mat-seeding method

Week 3

Direct-seeding method

Mat-seeding method

Week 6

Direct-seeding method

Mat-seeding method

Week 8

Direct-seeding method

Mat-seeding method

Week 10

Direct-seeding method

Mat-seeding method

$\begin{array}{lr}95.00 & 98.75 \\ 95.00 & 98.75 \\ 82.50 & 100.00 \\ 87.50 & 100.00\end{array}$

40.00

25.00

42.50

42.50

67.50

65.00

77.50

71.25
98.75

100.00

53.75

55.00

87.50

92.50

91.25

96.25

93.75

97.50
11.25

26.25

7.50

25.00

38.75

52.50 *

58.75

73.75

83.75

97.50 *

90.00

100.00

40.00

10.00

35.00

15.00 *

1996

(2)

31.25

26.25

18.75

6.25

15.00 *

41.25

42.50

11.25

11.25

8.75

$28.75^{*}$

63.75

66.25

10.00

11.25

$36.25 *$ *

${ }^{2}$ Means of observations based on percent plot coverage within similar species, seeding method, and year.

*, * Percent plot coverage means for a specific turfgrass are different at the 0.05 and 0.01 significance levels, respectively, within weekly observations within a year.

Table 5. Average weed counts taken 4 weeks after irrigated and nonirrigated study initiation on 11 and 13 May 1995 and 11 and 24 July 1996, respectively, comparing mat-seeded and direct seeding methods.

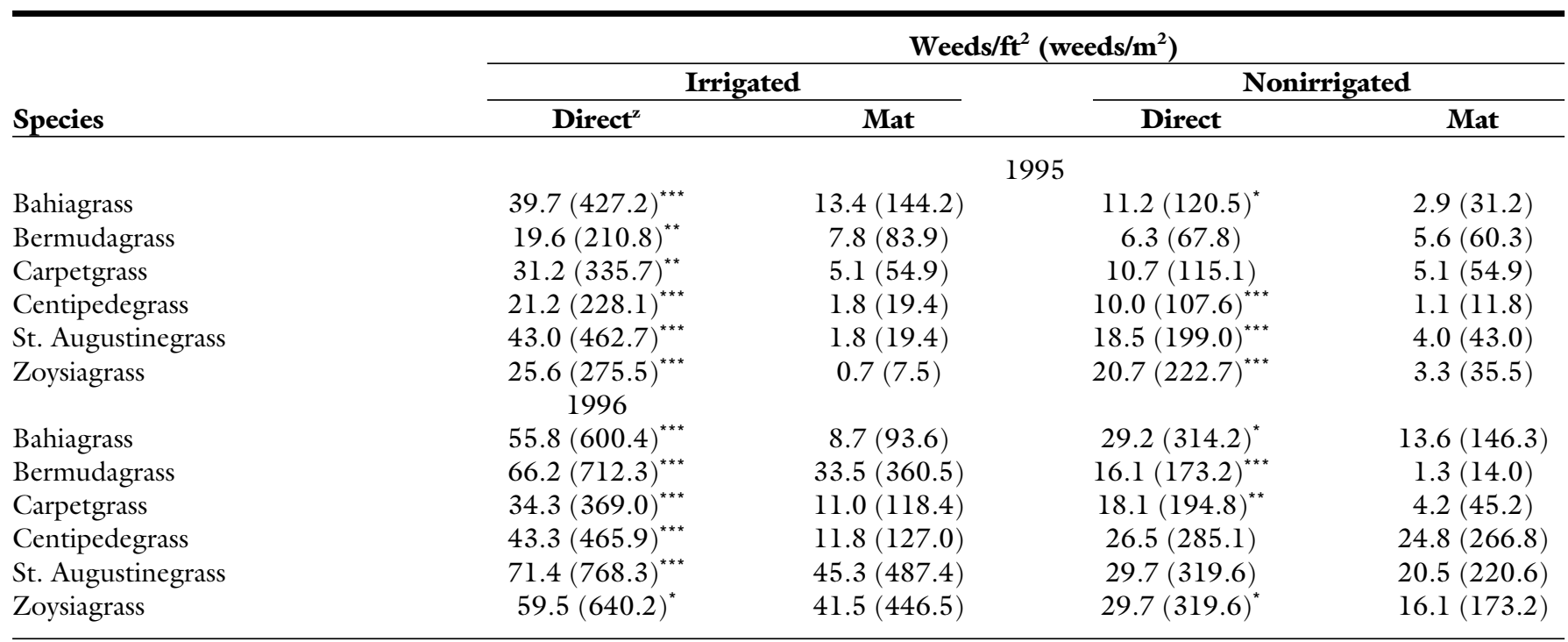

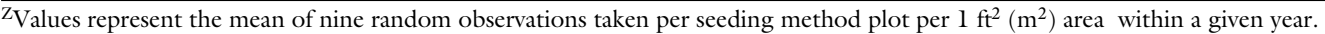

$*, * *{ }^{* *}$ Mean weed counts between seeding methods for a specific species within weekly observations within a year are significantly different at the $0.05,0.01$, and 0.001 significance levels, respectively.

carpetgrass coverage ratings were more variable, with centipedegrass establishing favorably for both seeding methods in the irrigated trials, and carpetgrass establishing favorably in the irrigated trial of 1996 and the nonirrigated trial of 1996. Establishment rates for st. augustinegrass or zoysiagrass were very poor for either seeding method or irrigation regime with the exception of $68 \%$ coverage for the direct seeded zoysiagrass under irrigated conditions in 1996 (Table 4). The limiting factors to seed establishment with these grasses may be problems with seed quality or preplanting seed treatment and not planting methods.

Weed suppression was the primary definite advantage gained by us- ing the seeded mat. In both years, weed suppression for mat-seeded plots in the irrigated and nonirrigated trials was superior. In some situations, matseeding was up to 38 times more effective in suppressing weed emergence versus the direct-seeding method. Decreased weed establishment is not only beneficial to turf establishment, but is also aesthetically desirable and 
economically appealing. By decreasing weed competition, the turfgrass plant has less competition for water and nutrients. Subsequent herbicide applications will be decreased resulting in economic savings with decreased weed establishment, and increased environmental consciousness.

A trade-off between the two seeding methods with respect to weed seedlings is evident. Direct-seeding results in more grass seedlings and more weeds, while mat-seeding results in less grass seedlings and less weeds. However, for grasses such as bermudagrass and bahiagrass, fewer grass seedlings early in establishment is of limited concern as the density corrects itself over time due to aggressive lateral growth.

Future research is needed to address optimum mat thicknesses for the individual turf species to enhance seed germination. Different results may be observed under alternative site conditions as opposed to the flat terrain, full sun conditions used here.

It is possible the seeded mat may show additional benefits on sloped terrain where soil erosion concerns would make direct-seeding a risky option, or where weed suppression is a primary concern during the first year of establishment.

\section{Literature cited}

Adams, J.E. 1966. Influence of mulches on runoff, erosion, and soil moisture depletion. Soil Sci. Soc. Amer. Proc. 30:110114.

Barkley, D.G., R.E. Blaser, and R.E. Schmidt. 1965. Effect of mulches on microclimate and turf establishment. Agron. J. 57:189-192.

Emmons, R. 1995. Turfgrass science and management. 2nd ed. Delmar Publ., Albany, N.Y.

Forbes, I., and M.H. Ferguson. 1948. Effects of strain difference, seed treatment, and planting depth on seed germination of Zoysia spp. J. Amer. Soc. Agron. 40:725732.

Harris, F.S., and H.H. Yao. 1923. Effectiveness of mulches in preserving soil moisture. J. Agr. Res. 23:727-742.

Hendricks, S.B., V.B. Toole, and H.A. Borthwick. 1968. Opposing actions of light in seed germination of Poa pratensis and Amaranthus arenicola. Plant Physiol.

\section{3:2033-2038}

Hensler, K.L. 1996. Evaluation of kenafbased fiber mat as an aid in turfgrass establishment. MS thesis. Miss. State Univ., Starkville.

Hensler, K.L., and B.S. Baldwin. 1995. Evaluation of commercial grass seed media for characteristics important to lawn establishment. Agron. Abstr. p. 153.

Hensler, K.L., B.S. Baldwin, and J.M. Goatley. 1998. Kenaf-based fiber mat as a substrate for establishing soilless sod. HortTechnology 8:171-175.

Madison, J.H. 1966. Optimum rates of seeding turfgrasses. Agron. J. 58:441-443.

McGinnies, W.J. 1960. Effects of moisture stress and temperature on germination of six range grasses. Agron. J. 52:159-162.

Murphy, R.P., and A.C. Arny. 1939. The emergence of grass and legume seedlings planted at different depths in five soil types. J. Amer. Soc. Agron. 31:17-28.

Musser, H.B. and A.T. Perkins. 1969. Guide to seedbed preparation, p. 462489. In A.A. Hanson and F.V. Juska (eds.). Turfgrass Sci. Agron. Monogr. 14. Amer. Soc. Agron., Madison, Wis.

Plummer, A.P. 1943. The germination and early development of twelve range grasses. J. Amer. Soc. Agron. 35:19-34.

Portz, H.L., J.J. Murray, and D.Y. Yeam. 1981. Zoysiagrass (Zoysia japonica Steud.) establishment by seed, p. 113-122. In: R.W. Sheard (ed.). Proc. 4th Intl. Turfgrass Res. Conf., Guelph, Ont. Canada. 19-23 July, 1981. Intl. Turfgrass Soc. Ontario Agr. College, Univ. Guelph, Guelph, Ont.

SAS Institute, Inc. 1987. SAS user's guide: Statistics. SAS Inst., Inc., Cary, N.C.

USDA. 1973. Soil survey of Oktibbeha Co., MS. U.S. Dept. Agr., Soil Conservation. Serv. and Forest Serv., in cooperation with Miss. Agr. Expt. Sta.

Watschke, T.L., and R.E. Schmidt. 1992. Ecological aspects of turf communities, $\mathrm{p}$. 129-174. In: D.V. Waddington, R.N. Carrow, and R.C. Shearman (eds.). Turfgrass. Agronomy Monogr. 32. Amer. Soc. Agron., Madison, Wis.

Yeam, D.Y., J.J. Murray, and H.L. Portz. 1981. Physiology of seed germination in zoysiagrass (Zoysia japonicaSteud.), p. 467476. In: R.W. Sheard (ed.). Proc. 4th Intl. Turfgrass Res. Conf., Guelph, Ont. Canada. 19-23 July, 1981. Intl. Turfgrass Soc. Ontario Agr. College, Univ. Guelph, Guelph, Ont. 